\title{
Redescription of the alpine Incurvaria stangei Rebel, 1903 (Lepidoptera, Incurvariidae), reinstated from Prodoxidae
}

\author{
Benjamin Wiesmair ${ }^{1}$, Peter Buchner ${ }^{2}$, Michael Kurz $^{3}$, Peter Huemer ${ }^{1}$ \\ 1 Tiroler Landesmuseen Betriebgsges.m.b.H., SFZ, Naturwissenschaftiche Sammlungen, Krajnc-Straße 1, 6060 Hall, \\ Austria; b.wiesmair@tiroler-landesmuseen.at; p.huemer@tiroler-landesmuseen.at \\ 2 Scheibenstraße 335, 2625 Schwarzau, Austria; buchner.324@drei.at \\ 3 Naturkundliche Gesellschaft, Josef-Waach-Straße 13/1, 5023 Salzburg, Austria; michael.kurz@gmx.at \\ http://zoobank.org/282B6590-CADE-4745-AA51-D64DDD4D7303
}

Received 28 November 2018; accepted 7 February 2019; published: 13 March 2018

Subject Editor: Erik van Nieukerken.

\begin{abstract}
Incurvaria stangei Rebel, 1903 revised combination, placed without justification in Prodoxidae, is redescribed and transferred back to the Incurvariidae. Male and female genitalia of this south-eastern alpine endemic species are illustrated for the first time. DNA barcode sequences as well as morphological traits support the revised family assignment.
\end{abstract}

\section{Introduction}

Incurvariidae and Prodoxidae are two out of formerly five (van Nieukerken et al. 2011), now six (Regier et al. 2015) known families of the superfamily Adeloidea Bruand, 1850. The type-species for Incurvariidae is Incurvaria masculella (Denis \& Schiffermüller, 1775) and for Prodoxidae Prodoxus decipiens Riley, 1880 (Nye and Fletcher 1991). The monophyly of both families is well supported by a morphologically based phylogenetic analysis (Nielsen and Davis 1985) and by recently published molecular studies (Mutanen et al. 2010; Regier et al. 2015).

Incurvaria stangei was described by Rebel (1903) from a single female collected in the Italian Dolomites (Südtirol, Tschierspitze, 31.vii.1902) by G. Stange. Shortly after this discovery a single male was found in the area of Triglav mountain range, currently Slovenia (Rebel 1907). Despite its extraordinary and unmistakable external appearance, this remarkable alpine species of primitive moth remained neglected for more than eight decades. Only in 1988 P. Huemer discovered a specimen and published a re-description, although without examination of genitalic structures (Huemer 1991). Nevertheless, he still treated the species in the family Incurvariidae Spuler, 1898. In contrast, Wojtusiak (1996) in the European Lepidoptera catalogue listed the species under Lampronia Stephens, 1829 in the family Prodoxidae Riley, 1881 for the first time, without giving arguments for the new combination. Subsequent publications followed this new taxonomic concept (e.g. Deutsch 2012; Huemer 2013; Karsholt and Nieukerken 2004-2011). However, Kurz (2002-2012), after dissection and careful examination of a female, reconsidered the taxonomy and informally recombined the species in Incurvaria Haworth, 1828 (Incurvariidae). This work 
is now supported after an extensive analysis of characters of the male and female genitalia and cytochrome $c$ oxidase subunit I (COI-5P) DNA barcodes and we therefore now formally present this revised combination.

\section{Material and methods}

Our study is based on examination of ten specimens of I. stangei which are all deposited in the collections of the Tiroler Landesmuseum Ferdinandeum, Natural History Collections, Hall, Austria. Genitalia preparations followed standard techniques (Robinson 1976), with some modifications, especially the implementation of the so-called unrolling technique in male genitalia (Pitkin 1986). Although genitalia of both sexes are strongly sclerotized, male preparations were slightly stained with Mercurochrome and females with Chlorazol to highlight delicate structures. For photos, genitalia of both sexes were embedded in Euparal with ventral side up, male genitalia being unrolled. Additionally, male genitalia were photographed in their natural three-dimensional shape before spreading, both from lateral and dorsal aspect. Photos of adults were taken with a Canon EOS 5D Mark III and Canon lens MP-E 65 at 2:1, using a ring flash. Genitalia photos were taken with a microscope (Wild Heerbrugg) using a 10x objective and a 2.5x ocular. All photos were edited using the software HELICON FOCUS 4.80 and ADOBE PHOTOSHOP 6.0. For sequencing a single leg was removed, placed in a 96-well lysis plate and sent for analysis to the CCDB (Canadian Centre for DNA Barcoding, University of Guelph, Canada) where DNA extraction, PCR amplification, and sequencing were performed following standard high-throughput protocols (DeWaard et al. 2008). A Neighbor-Joining (NJ) tree of 26 European species of Incurvariidae and Prodoxidae plus a species of the type genus Prodoxus Riley, 1880 was constructed using MEGA 7 (Kumar et al. 2016). This tree is based on 132 barcode sequences which are available in the public dataset "DS-LEPIINCU Lepidoptera - Incurvarioidea" in the Barcode of Life Datasystems BOLD (Ratnasingham and Hebert 2007). Node confidences were assessed using 500 bootstrap replicates.

Abbreviations:

NHMW Naturhistorisches Museum, Wien, Austria.

TLMF Tiroler Landesmuseum Ferdinandeum, Innsbruck, Austria.

\section{Results}

\section{Incurvaria stangei Rebel, 1903, revised combination}

Lampronia stangei (Rebel, 1903) Wojtusiak 1996: page 29.

Type material. Holotype, female: Italy, South Tyrol, Tschierspitze, Felsgebiet nördlich des Grödner Jochs, 2500 m, 31.vii.1902, leg G. Stange, NHMW [not examined, see remarks].

Material examined. Austria: 1 male, East Tyrol, Lienzer Dolomiten, Karlsbaderhütte, 2300-2400 m, 02.viii.2013, leg. H. Deutsch, TLMF, barcode sample ID BC TLMF Lep 24036; 1 male, East Tyrol, Laserzgebirge, Lavanter Almtal, 1200 m, 27.vii.2012, leg. H. Deutsch, TLMF. Slovenia: 3 male, 1 female, Goriška, Julische Alpen, Triglav, Planika-Hütte, 2400 m, 05.viii.1991, leg. H. Habeler, TLMF; 1 male, Goriška, Julis- 


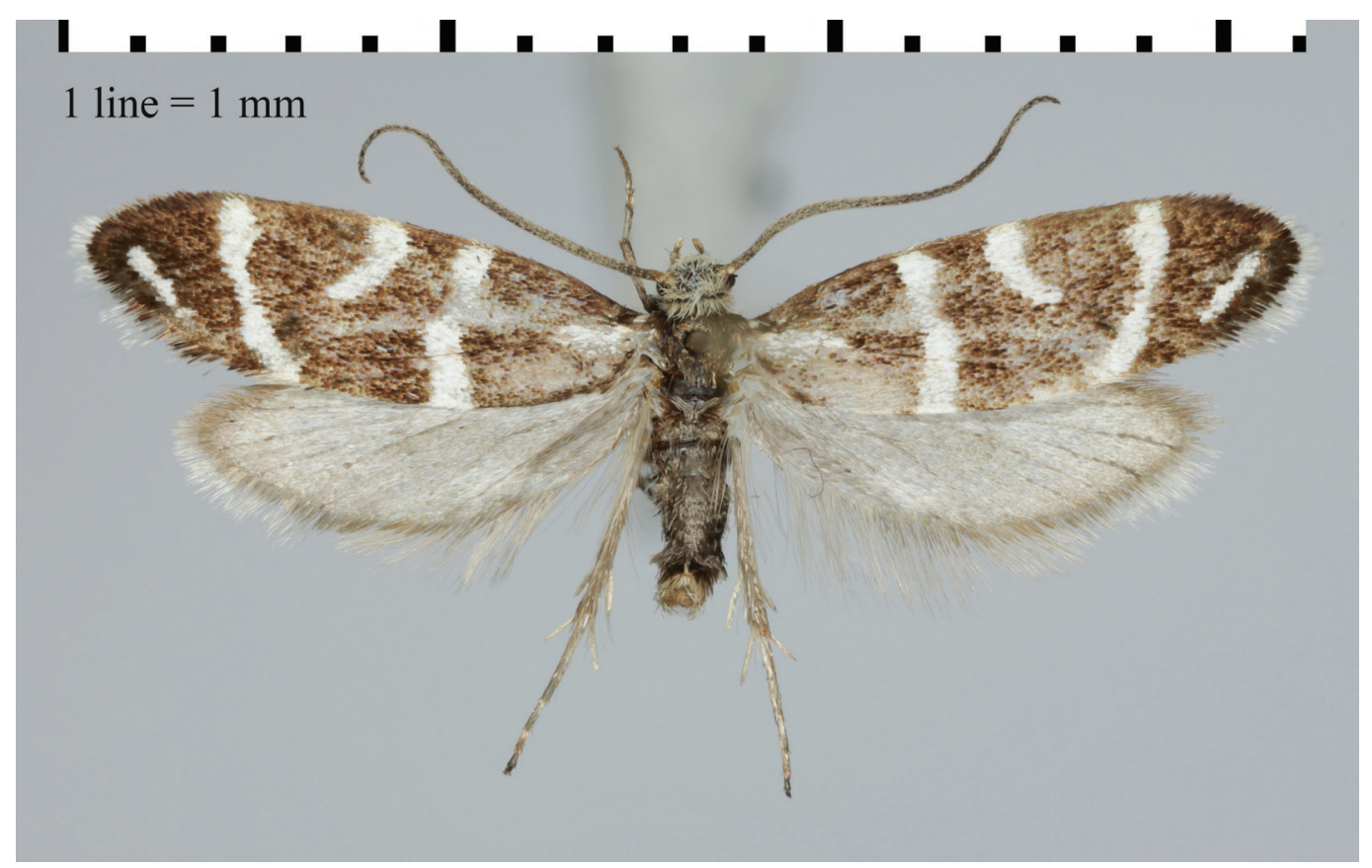

Figure 1. Incurvaria stangei Rebel, 1903, male, Austria, East Tyrol, Laserzgebirge, Lavanter Almtal, 1200 m, 27.vii.2012, leg. H. Deutsch.

che Alpen, Kamin, Podi, 2200-2300 m, 19.vii.1996, leg. H. Deutsch, TLMF. Italy: 1 male, Friuli-Venezia Giulia, Udine, Monte Sernio Massiv, Forcella Nuviernulis, 1700 m, 16.vii.1988, leg. P. Huemer, TLMF; 1 female, Lombardia, Bergamo, Alpi Orobie, Pizzo Arera, 2500 m, 20.vii.1992, leg. P. Huemer \& G. Tarmann, TLMF; 1 male, Friuli-Venezia Giulia, Pordenone, Val Montanaia, linker Talhang/ Cimolais N, 2100 m, 23.vi.2017, leg. B. Wiesmair \& P. Schattanek, TLMF, barcode sample ID BC TLMF Lep 24036.

Description. Adult (Figs 1, 2). Forewing length: male ( $\mathrm{n}=8), 7.0-8.0 \mathrm{~mm}$; female $(\mathrm{n}=2), 5.5-6.5 \mathrm{~mm}$. Head covered with yellowish scales, frons whitish; eyes hemispheric, black; labial palpi bright yellowish brown, apically whitish; antennae in both sexes delicately ciliated, brown, covered with small white scales in fresh specimens; thorax brownish black with golden shine; abdomen greybrown; ground colour of forewing upper side black-brown with a distinct white wing pattern consisting of: a short longitudinal basal streak, two fasciae developed as small narrow bands, inner fascia at $1 / 3$ of the wing length runs from costal to dorsal margin (costal nearer to wing-base), outer fascia at 3/4 is arranged in the opposite direction, costal margin at $1 / 2$ with a subtriangular spot, a short horizontal streak in the marginal area near the apex of the wing, fringes basal brownish black, distal white. Underside with the same pattern, but more blurred. Hindwings shiny grey, fringes basally dark grey, distal part brighter grey to white; legs dirty white to beige, tibiae and tarsi brownish beige, fore-tibia without epiphysis, hind-tibia with a pair of pre-apical spurs, with a long tuft of hair-like scales and a pair of long apical spurs.

DNA barcode. BOLD (BIN): BOLD:ADI9579, (Process ID): 


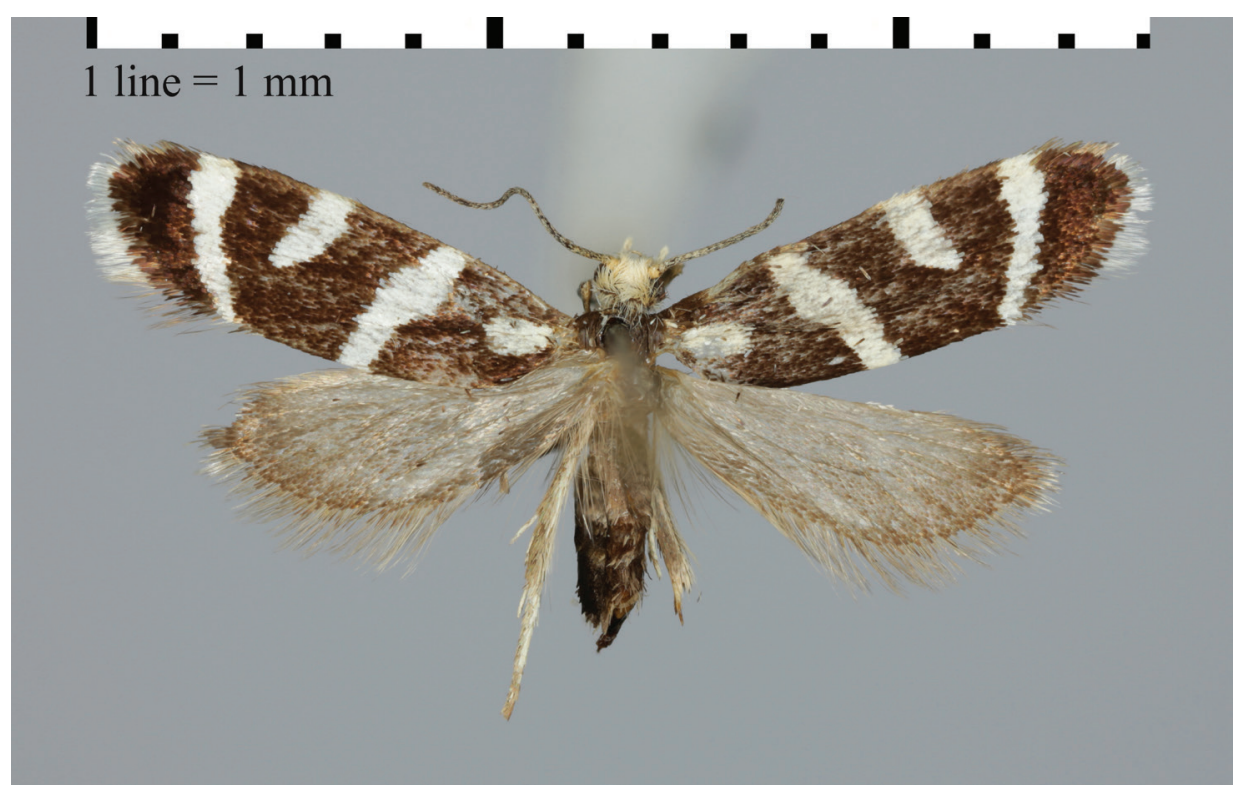

Figure 2. Incurvaria stangei Rebel, 1903, female, Slovenia, Goriška, Julische Alpen, Triglav, Planika-Hütte, 2400 m, 05.viii.1991, leg. H. Habeler.

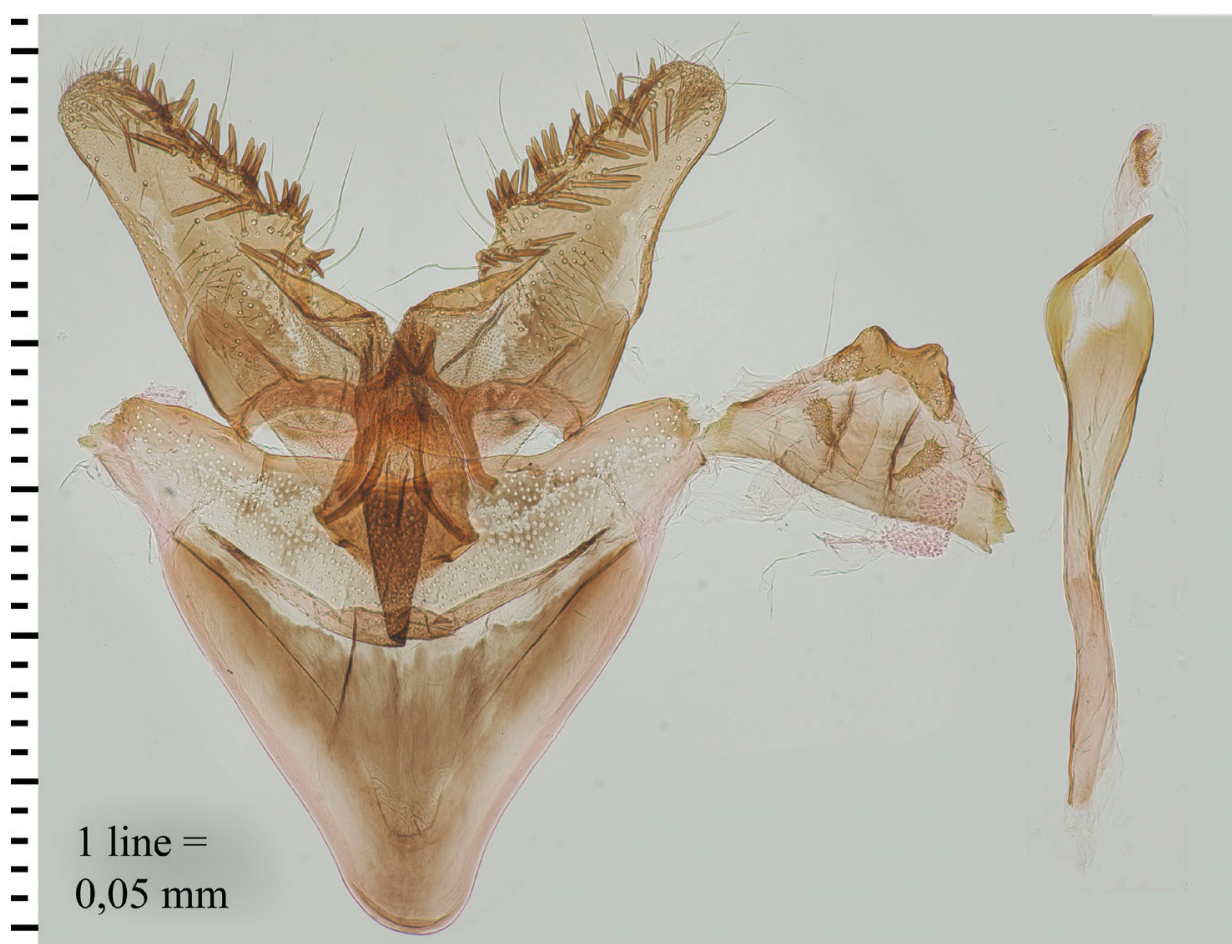

Figure 3. Unrolled male genitalia of Incurvaria stangei Rebel, 1903, Slovenia, Goriška, Julische Alpen, Triglav, Planika-Hütte, 2400 m, 05.viii.1991, leg. H. Habeler, Gen.Präp. m3331 P. Buchner. 

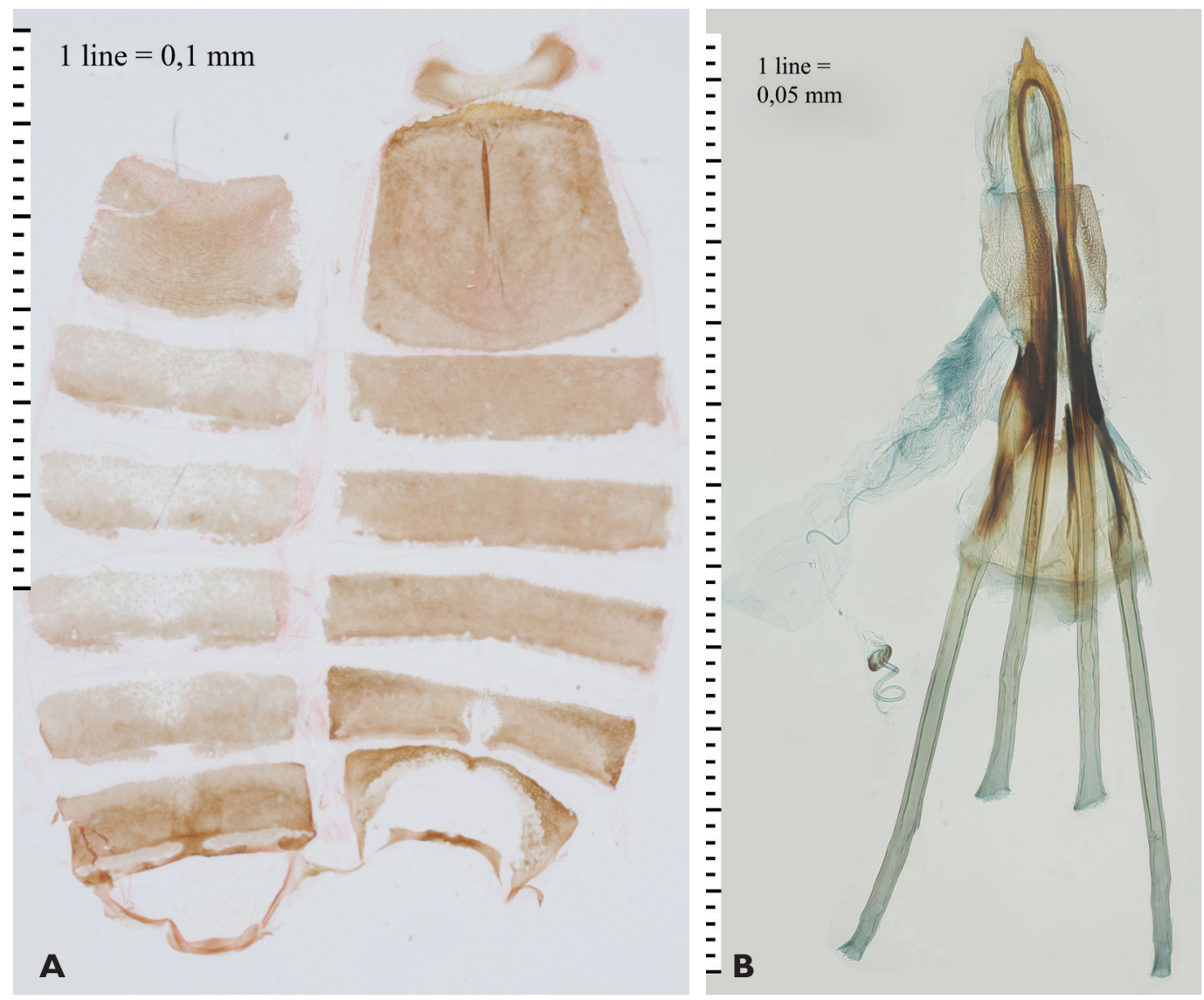

Figure 4. left: Female abdominal segments, right: Female genitalia of Incurvaria stangei Rebel, 1903, Slovenia, Goriška, Julische Alpen, Triglav, Planika-Hütte, 2400 m, 05.viii.1991, leg. H. Habeler, Gen.Präp. w3349 P. Buchner.

Male genitalia (Fig. 3). Uncus and tegumen short, forming a trapezoid plate, posterior margin of uncus medially concave forming a double lobed structure; socius distinctly sclerotized, clubshaped, long, distally widened; transtilla with distinct medial knob and strongly sclerotized lateral arms; sub-medial anterior projections relatively long, finger-shaped and of equal width, ending in an edge; valva short and robust; costal margin slightly concave; cucullus hirsute, with a set of distinct spines along the margin, apex hirsute and rounded; vinculum V-shaped, broad and short, distal end broad and rounded.

Female genitalia (Fig. 4). Pre-genital segments. Sternum VII as well as tergum VII of rectangular shape. Posterior part of ovipositor triangular, tip rounded, lateral margins concave with two steps; apophyses posteriores and anteriores both relatively long, with blunt ends; ductus bursae as well as bursa copulatrix short, the latter bulky and without signa; ductus spermathecae with several convolutions.

Diagnosis. Due to the unique colouration and pattern of the forewings of both sexes, I. stangei can be easily separated from all other members of Adeloidea.

Bionomics. The biology of I. stangei is unknown; the host plant as well as primary stages are still undiscovered. Huemer (1991) assumed that adults are active in the early morning hours before 


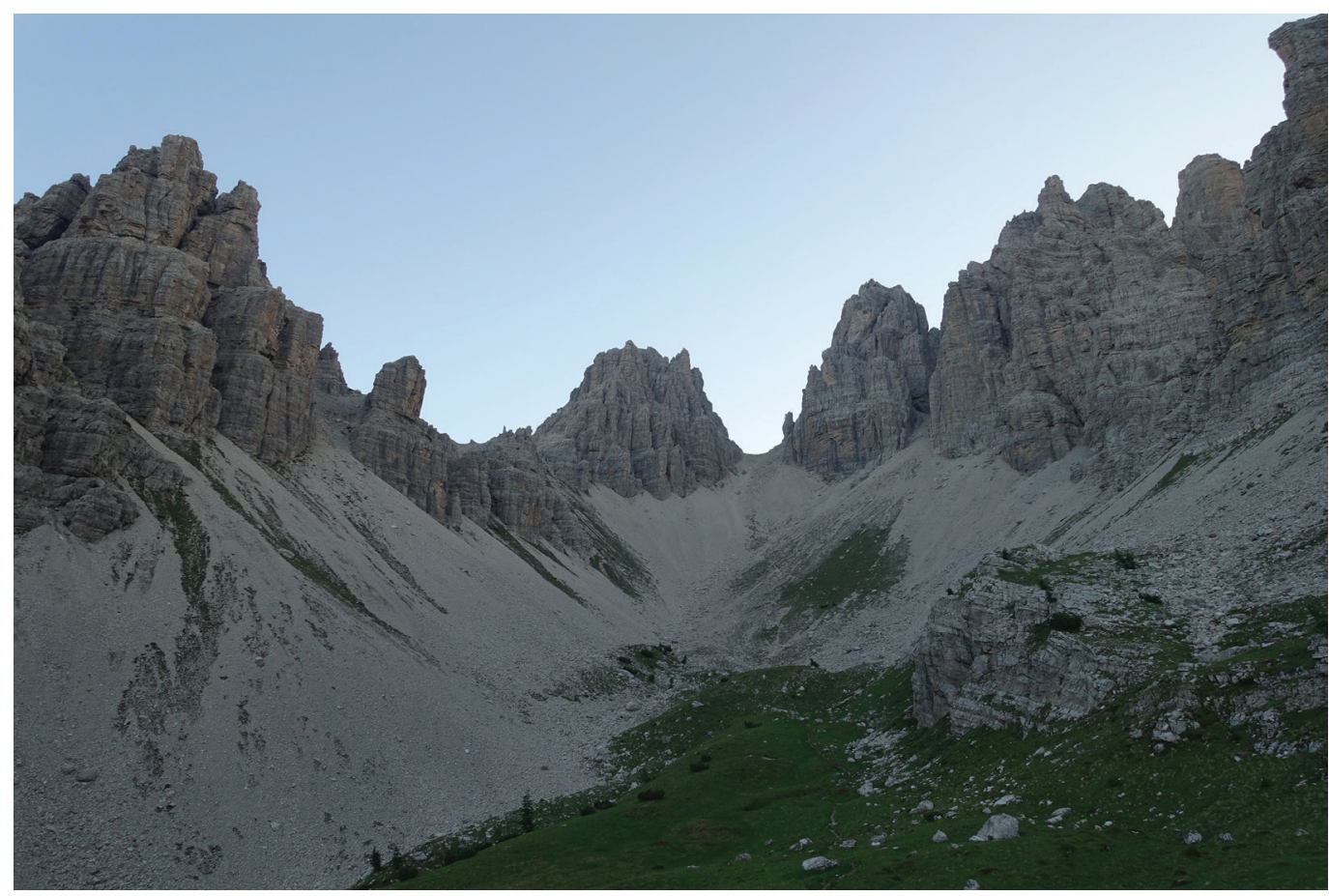

Figure 5. Habitat of Incurvaria stangei Rebel, 1903 in Friuli-Venezia Giulia, Pordenone.

sunrise, similar to some other alpine incurvariids such as e.g. I. vetulella (Zetterstedt, 1839). However, Deutsch (2012) also reported attraction to artificial light. The poorly known life habits likely explain the small number of observed individuals. The adults were found in the second half of July, mainly at the border zone between the subalpine shrubs and alpine meadows from about 1700 to 2500 m elevation (Huemer 1991) (Fig. 5). Deutsch (2012), however, found a single male at a lower elevation $(1250 \mathrm{~m})$, which is suspected to have been drifted from its natural habitat.

Distribution. The species is endemic to the south-eastern Alps: Julian Alps: Slovenia, Goriška (Carnelutti 1978; Habeler and Gomboc 2005; Govedič and Lesar 2010; Rebel 1907); Carnic Alps: Italy, Friuli-Venezia Giulia (Huemer 1991; unpublished record), Austria, East Tyrol (Deutsch 2012); Dolomites: Italy, South Tyrol (Rebel 1903); Orobian Alps: Italy, Lombardia (unpublished record).

Remarks. Despite of a personal search by PH, the holotype could not be traced at NHMW. The Rebel collection only contains a label of the species but without any evidence of the specimen, even a pinhole is absent.

\section{Discussion}

The family concept of Incurvariidae and Prodoxidae and consequently the correct combination of genera and species remained obscure through most of the $20^{\text {th }}$ century. Even in some recent literature the European genera of Prodoxidae were lumped in the family Incurvariidae (Karsholt et al. 


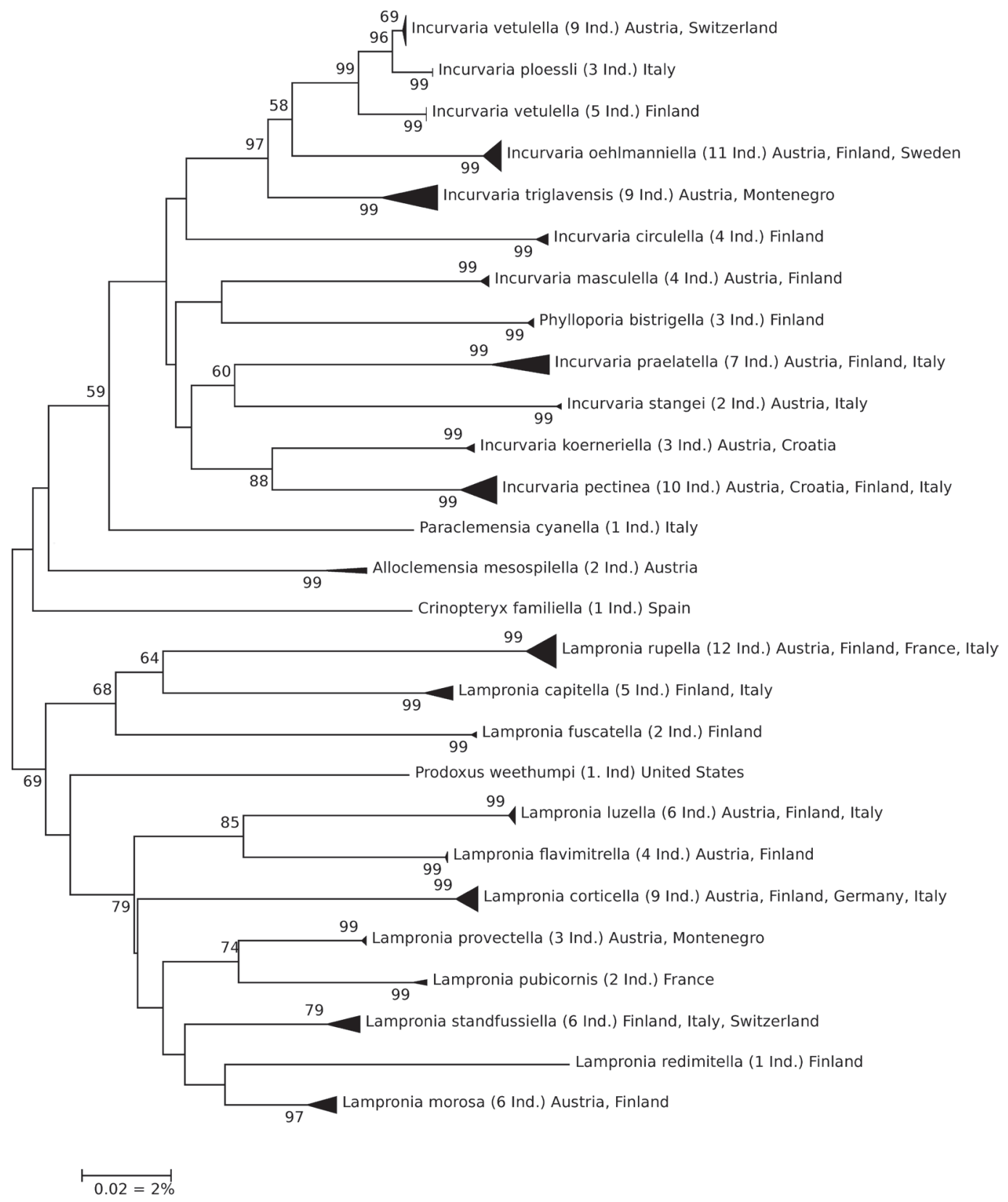

Figure 6. Neighbor-Joining tree based on DNA barcodes (658 bp fragment of the mt COI gene) of European Incurvariidae and Prodoxidae. The node support values in percentages are based on 500 bootstrap replicates.

1995). However, already Nielsen $(1982,1985)$ convincingly separated these families based on diagnostic characters, primarily of male and female genitalia morphology. Accordingly, males of Prodoxidae can be recognized by the presence of well-defined pectinifers of the valva, whereas in the female genitalia, Prodoxidae possess a pair of stellate signa in the corpus bursae and a posteri- 
orly well-rounded sternum VII and a triangular tergum VII. Furthermore, the larvae of Prodoxidae - as far as known - are endophagous in herbs and shrubs, whereas nearly all larvae of Incurvariidae are free living in self-constructed cases.

The male genitalia of $I$. stangei lack the family characteristic pectinifers typical of Prodoxidae and the more flattened, scale-shaped spines of the valva are grouped together. These characteristics support the placement of I. stangei in Incurvariidae. Similarly the female genitalia of I. stangei, which completely lack stellate signa, perfectly fit into the concept of Incurvariidae as proposed by Nielsen (1982). Furthermore, sternum and tergum VII are both of rectangular shape, characteristic for Incurvariidae. In contrast, a posteriorly well-rounded sternum VII and a triangular tergum VII is considered diagnostic for Prodoxidae (Nielsen 1982).

A Neighbor Joining tree analysis was derived from DNA barcode sequences (COI) of selected European species of Incurvariidae and Prodoxidae with I. stangei nesting in Incurvariidae. Considering a mean interspecific distance of $8.5 \%$ (min. 1.2\%, max. 13.7\%) in Incurvariidae, I. stangei shows a remarkable distance (12\%) to its closest species, Paraclemensia acerifoliella (Fitch, 1854), from North America, while it is over $12.3 \%$ to Incurvaria praelatella (Fig. 6).

\section{Acknowledgments}

We are particularly grateful to Paul Hebert and his team at the Canadian Centre for DNA Barcoding (Guelph, Canada) whose sequencing work was enabled by funding from the Government of Canada to Genome Canada through the Ontario Genomics Institute. We are also grateful to the Ontario Ministry of Research and Innovation and to NSERC for their support of the BOLD informatics platform. We are indebted to the Promotion of Educational Policies, University and Research Department of the Autonomous Province of Bolzano - South Tyrol for helping to fund the project "Genetische Artabgrenzung ausgewählter arktoalpiner und boreomontaner Tiere Südtirols". Marko Mutanen (Oulu, Finland) kindly granted us full access to his valuable sequences of Incurvariidae and Prodoxidae in BOLD. We are finally grateful to Petra Schattanek for the photograph of the habitat. Last but not least we owe gratitude to Mikhail Kozlov (University of Turku, Finland) and Erik van Nieukerken (Naturalis, Leiden, The Netherlands) for helpful comments.

\section{References}

Carnelutti J (1978) Živalski svet Triglava. Proteus 41(3): 83-87.

Deutsch H (2012) Lampronia stangei Rebel, 1903 (Lepidoptera: Prodoxidae): ein überraschender Fund in den Lienzer Dolomiten und Erstnachweis für Österreich. Zeitschrift der Arbeitsgemeinschaft Österreichischer Entomologen 64: 71-72.

DeWaard JR, Ivanova NV, Hajibabaei M, Hebert PDN (2008) Assembling DNA Barcodes: Analytical Protocols. In: Cristofre M (Ed.) Methods in Molecular Biology: Environmental Genetics. Humana Press Inc., Totowa, 275-293. https://doi.org/10.1007/978-1-59745-548-0_15

Govedič M, Lesar T (2010) Check list of Slovenian Microlepidoptera. Natura Sloveniae 12: 35-125.

Habeler H, Gomboc S (2005) Bemerkenswerte Schmetterlingsfunde aus Slowenien mit Erstnachweisen. Acta Entomologica Slovenica 13: 29-52.

Huemer P (1991) Incurvaria stangei Rebel, 1903, ein bemerkenswerter Kleinschmetterling aus den Südalpen (Lepidoptera, Incurvariidae). Berichte des naturwissenschaftlich-medizinischen Vereins in Innsbruck 78: 173-175.

Huemer P (2013) Die Schmetterlinge Österreichs (Lepidoptera). Systematische und faunistische Checkliste Studiohefte 12. Tiroler Landesmuseen-Betriebsges.m.b.H., Innsbruck, 304 pp. 
Karsholt O, Nieukerken EJ van (Eds) (2004-2011) Lepidoptera, Moths. Fauna Europaea versions 1.1-2.4. http://www.faunaeur.org [Accessed 22.ix.2018]

Karsholt O, Nieukerken EJ van, Whitebread S, Zangheri S (1995) Lepidoptera Zeugloptera, Dacnonypha, Exoporia, Monotrysia (=Micropterigoidea, Eriocranioidea, Hepialoidea, Nepticuloidea, Incurvarioidea, Tischerioidea). In: Minelli A, Ruffo S, La Posta S (Eds) Checklist delle specie della fauna italiana 80. Calderini, Bologna, 1-12.

Kurz MA, Kurz ME (2000-2012) Naturkundliches Informationssystem. http://www.nkis.info/nkis/extaustaxonshow.cgi?uid=TaxOn\&tax=339\&lang=e [Accessed 10.ix. 2018]

Kumar S, Stecher G, Tamura K (2016) MEGA7: Molecular Evolutionary Genetics Analysis version 7.0. Molecular Biology and Evolution 33: 1870-1874. https://doi.org/10.1093/molbev/msw054

Mutanen M, Wahlberg K, Kaila L (2010) Comprehensive gene and taxon coverage elucidates radiation patterns in moths and butterflies. Proceedings of the Royal Society B 277: 2839-2849. https://doi.org/10.1098/ rspb.2010.0392

Nielsen ES (1982) Incurvariidae and Prodoxidae from the Himalayan area (Lepidoptera: Incurvarioidea). Insecta Matsumurana 26: 187-200.

Nielsen ES (1985) The monotrysian heteroneuran phylogeny puzzle: a possible solution. Proceedings of the $3^{\text {rd }}$ Congress of Lepidopterology, Cambridge, 138-143.

Nielsen ES, Davis DR (1985) The first southern hemisphere prodoxid and the phylogeny of the Incurvarioidea (Lepidoptera). Systematic Entomology 10: 307-322. https://doi.org/10.1111/j.1365-3113.1985.tb00140.x

Nieukerken EJ van, Kaila L, Kitching IJ, Kristensen NP, Lees DC, Minet J, Mitter C, Mutanen M, Regier JC, Simonsen TJ, Wahlberg N, Yen S-H, Zahiri R, Adamski D, Baixeras J, Bartsch D, Bengtsson BÅ, Brown JW, Bucheli SR, Davis DR, Prins J De, Prins W De, Epstein ME, Gentili-Poole P, Gielis C, Hättenschwiler P, Hausmann A, Holloway JD, Kallies A, Karsholt O, Kawahara A, Koster SJC, Kozlov M, Lafontaine JD, Lamas G, Landry J-F, Lee S, Nuss M, Park KT, Penz C, Rota J, Schmidt BC, Schintlmeister A, Sohn JC, Solis MA, Tarmann GM, Warren AD, Weller S, Yakovlev RV, Zolotuhin VV, Zwick A (2011) Order Lepidoptera Linnaeus, 1758. In: Zhang Z-Q (Ed.) Animal biodiversity: An outline of higher-level classification and survey of taxonomic richness. Zootaxa 3148: 212-221.

Nye IWB, Fletcher DS (1991) The generic names of the moths of the world. Vol. 6. Microlepidoptera. Natural History Museum Publications, London, 368 pp.

Pitkin L (1986) A technique for the preparation of complex male genitalia in Microlepidoptera. Entomologist's Gazette 37: 173-179.

Ratnasingham S, Hebert PDN (2007) BOLD: The Barcode of Life Data System (http://www.barcodinglife. org). Molecular Ecology Notes 7: 355-364. https://doi.org/10.1111/j.1471-8286.2006.01678.x

Rebel H (1903) Neue Microheteroceren aus Österreich-Ungarn. Verhandlungen der kaiserlich-königlichen zoologisch-botanischen Gesellschaft in Wien 53: 90-103.

Rebel H (1907) Lepidopteren aus dem Gebiete des Triglav und der Crna Prst in Krain. I. Nachtrag. Jahresberichte Wiener entomologischer Verein 17: 33-60.

Regier JC, Mitter C, Kirstensen NP, Davis DR, Nieukerken EJ van, Rota J, Simonsen TJ, Mitter KT, Kawahara AY, Yen S-H, Cumming MP, Zwick A (2015) A molecular phylogeny for the oldest (nonditrysian) lineages of extant Lepidoptera, with implications for classification, comparative morphology and life-history evolution. Systematic Entomology 40(4): 671-704. https://doi.org/10.1111/syen.12129

Robinson G (1976) The preparation of slides of Lepidoptera genitalia with special reference to the Microlepidoptera. Entomologist's Gazette 27: 127-132.

Wojtusiak J (1996) Prodoxidae. In: Karsholt O, Razowski J (Eds) The Lepidoptera of Europe. A Distributional Checklist. Apollo Books, Stenstrup, 29-30. 